\title{
An Investigation into a Link between Classroom Climate and Reading Achievement
}

\author{
Ria Oktaviani \\ An English Teacher of Junior High School Fauziah Palembang, South Sumatera, Indonesia \\ riaoktaviani928@gmail.com
}

\begin{abstract}
This research investigated a link between classroom climate and reading achievement, and discovered the influence of the classroom climate and reading achievement of the students at one junior high school in Palembang, South Sumatera, Indonesia. Fifty seven students participated in this study and were chosen by using convenience sampling method. In collecting the data, Constructivist Learning Environment Survey (CLES) and reading test were used. Descriptive statistics, Pearson Product Moment Correlation and regression analysis were employed to analyze the data. Based on the data analysis, it was found out that $\mathrm{r}(.175)<_{\mathrm{r}}$ table $(.260)$ was higher than 0.05. It designated that the classroom climate and students' reading achievement were not significantly correlated. Since there was so significant link, it was not necessary to conduct further investigation, regression analysis, to check the influence of classroom climate and students' reading achievement. It can be determined that classroom climate did not give substantial influence on students' reading achievement.
\end{abstract}

Keywords: classroom climate, students' reading achievement

\section{Manuscript submitted: June 24, 2018 \\ Manuscript revised: September 3, 2018 \\ Accepted for publication: September 17, 2018}

\section{Introduction}

Education is essential for the development of society. Abrar, Mukminin, Habibi, Asyrafi, Makmur, and Marzulina (2018) state that the 1989 law on the Indonesian educational system gives English a place as the first foreign language among other foreign languages used in Indonesia such as German, Arabic, or Japanese (as cited in Marzulina., 2018, p.64). There are four English language abilities in studying English. The prominent skill to be mastered is reading. It allows learners to understand all new things in English written form. Wallace states reading is so much a part of daily life for those of us who live in literate communities that much of the time we hardly considerate her the purposes or processes involved (as cited in Ariesca \& Marzulina, 2016, P.25). Mikulecky and Jeffries (1996) state that the students are expected to master the reading skill to develop their knowledge, improve their skill, and increase their involvements. The students can increase their abilities and achieve their need for information.

Ironically, Wasliman (2003) argues reading achievement of Indonesian learners among East Asia learners still has to be improved. The International Association for the Evaluation of Education Achievement in East Asia reports the reading skill of Indonesian learners is the worst in this area. Indonesian learners only understand 30\% reading resources. Horsburgh says that the skill of reading and an interesting reading can only be developed properly by allowing the reader to read and enjoy a number of reading texts (as cited in Saputra\& Marzulina, 2015, p.189). The 
learners discover difficulties in reading substances that need intellectual development. Because of the learners' low reading quality, the Indonesian schools learning process at Indonesian schools nowadays do not support the students' intellectual development. It is also supported by Hidi (as cited in Marzulina \& Rumainah, 2018, p.55) who argues that interest has an important role in reader's text.

Besides, according to Kusmana (2009), from the outcomes of the Program for Research International Student Assessment, it indicates that the learners' reading interests are bad. Indonesian students' reading interests are the worst compared to countries in East Asia. From 42 countries surveyed, Indonesian learners are in the 39 position, higher than Albania and Peru. In mastering the material from the reading, the learners just understand $30 \%$ of the material showed in the text. According to Kumaravadivelu (2008), in learning process, there are several features or topics that disturb learners' achievement, including in reading. Abrar, Mukminin, Habibi, Asyrafi, Makmur, and Marzulina. (2018) state that "external factors, such as classroom environment, and negative comments from teachers and peers, may hinder the learners from actively engaging" (p.131). Based on the previous statement, one of the features that can affect students' achievement is environment which related to the climate. According to Leone (2009), classroom climate is the classroom environment connecting public views of the learners and teachers. In addition, Fraser (1994) states students will get enhanced and have more knowledge if a positive classroom climate is made. It can be said that this thing is one of the most current and dominant tools that can be used by the teachers to encourage student in studying process. In short, classroom climate is needed to gain comprehension in reading a passage.

After having an interview to the students at one state junior high school in Palembang, the students were having some difficulties in reading comprehension part. Having bad motivation in learning English is one of the reasons that influenced the students, especially in reading. I also tried to interview the teachers at state junior high school in Palembang. They said that the learners did not do the assignment seriously; they do not really care on teacher's talk. The learners were passive in learning English and were not eager to follow the English activities in the class until it was done. As stated before, it implied that the learners had bad score of their reading achievement from bad classroom classmate. It is in line with what Leone (2009) examines on students' achievement in classroom climate. In learning reading achievement, the learners have individual needs, like meaningful interactions with their learning classroom climate. Therefore, it is important to investigate a link between students' reading achievement and classroom climate, and to classify how far it influences their reading achievement.

\section{Literature Review}

\section{Classroom climate}

According to Cropley (1992), interpersonal condition and emotional condition are two conditions that established the climate among students. It generally discusses about classroom relationship and classroom cohesion. Classrooms which recommend better opportunities for learning and make learners become doing well are characterized by greater cohesion and goaldirection, lesser extent of disorganization and conflicts. Meantime, Murray (1938) states that classroom climate is usually conceptualized as a set of regular entities whose existence and dimensionality may be inferred from learners' and teachers' thoughts of psychosocial attributes of the classroom social system.

\section{Reading achievement}

Cline, Johnson, and King (2006) define three meanings about reading; reading means decoding and understanding written passage, reading means decoding and understanding passage for exacting reader's aims and reading is the development of obtaining meaning from text. 
According to Arifin (1990), "achievement" is an action, an ability, and people manner in resolving something. Furthermore, Sukarta (2000) states achievement is an output about attitude, knowledge, skill, behavior, and accomplished by learners after following teaching and learning activity during certain time.

In line to reading, achievement in reading is the effect of learners' perceptive of a passage or some passages. If students' experiences are successful, their requirement for achievement will so be reinforced. It also happens in reading. Learners who are successful in reading; the requirement for achievement in reading will also be reinforced.

\section{The link between classroom climate and reading achievement}

Classroom climate functions as a fuel to start all actions performed by people, whereas the learning achievement is as a motor that plays all actions which depend on the capability of fuel itself. Koth (2008) states that morals, collective principles, and dispositions create the links between all learners in the school and create suitable behaviors and norms for the learning society. Good notice to the classroom climate will influence to the achievement in reading achievement. One of the significant abilities that learners must be possessed is reading. Obtaining comprehension about the passage that the learners have read is the major aim of reading. Some learners lack of vocabulary mastery. Therefore, they are having problem in comprehension a text. Accordingly, for getting their success in learning process, the learners should be independent to discover other sources to help them. To sum up, classroom climate is important for the students in comprehending the reading text.

\section{Methodology}

\section{Research design, research site, sampling, and participants}

In doing this research, correlational research method was used. In particular, this research explored whether or not there was a major link between classroom climate and the learners' reading achievement, and whether learners' classroom climate influenced their reading achievement. The sample of this research was fifty-seven students of state junior high school in Palembang, South Sumatera, Indonesia. This research used convenience sampling method.

\section{Data collection}

Ready-made questionnaire, Constructivist Learning Environment Survey (CLES), a questionnaire which was adapted from Taylor and Fraser (1991) were used in this research. The questionnaire had 30 items. These 30 items were divided into five groups of statements. Those 5 scales involved Personal Relevance (PR), Uncertainty of Science (US), Critical Voice (CV), Shared Control (SC), and Student Negotiation (SN). I distributed not only the questionnaire, but also the reading test. Allocated the time for learners to answer the test was 50 minutes and the test consisted of 42 multiple choice questions.

\section{Data analysis}

First, data from questionnaire were analyzed. The smallest amount score of each item was 1 and highest score was 5 . The smallest sum score of each CLES scale was 5 and the maximum sum score was 30, whereas the smallest sum score of all the five scales was 30 and the maximum was 150. To analyze the frequency and percentage of each perception of classroom, climate outcomes were classified. Second, the outcome of students' reading achievement test was tested manually by using scoring system. For correct answer, the score was 100. For incorrect answers, the score was 0 . 


\section{Findings and Discussion}

\section{Classroom climate and students' reading achievement}

The highest score was 138, and the lowest score was 75. Itshowed for the descriptive statistical analysis of CLES of the participants. 99.46 was the mean of the classroom climate scores for the participant and the standard deviation was 12.093. Then, the descriptive statistical analysis for reading achievement represented that the highest score was 95, and the lowest score was 19. The mean of the reading achievement scores for the participants was 85.96 and the standard deviation was 11.381. This mean score showed that the level of reading achievement of participants was good.

\section{The result of normality and linearity test}

Two pre-requisite analyses were done prior to correlation and regression analysis, namely linearity and normality test. The data were interpreted normal if $\mathrm{p}>0.05$. If $\mathrm{p}<0.05$. KolmogorovSmirnov was conducted to observe the normality. The outcome of normality test is that all data from each variable normal and suitable for data analysis with coefficients .873 for classroom climate and .008 for reading achievement. For linearity test, deviation of linearity was obtained. If probability was not less than .05 , the two variables are linear. The results indicated that the deviation from linearity between classroom climate and reading achievement was .453. In short, all the data were linear for each correlation and regression.

\section{Link between classroom climate and students 'reading achievement}

Based on Pearson Product Moment Correlation Coefficient, the outcome showed that there was no major link between classroom climate and reading achievement. The relationship coefficient or the r-obtained (.175) was not higher than r-table (0.2609). Then the level of probability (p) significance (sig.2-tailed) was .194. So that $\mathrm{p}$ (.194) was not lower than .05. Thus, there was no significant relationship between the learners' classroom climate and reading achievement.

Table 5. Link between classroom climate and reading achievement

\begin{tabular}{llrr}
\hline & & Classroom Climate & Reading Achievement \\
\hline \multirow{2}{*}{ Classroom Climate } & Pearson & 1 & .175 \\
& Correlation & & .194 \\
& Sig. (2-tailed) & 57 & 57 \\
& $\mathrm{~N}$ & .175 & 1 \\
\hline \multirow{2}{*}{ Reading Achievement } & Pearson & .194 & \\
& Correlation & 57 & 57 \\
& Sig. (2-tailed) & . & \\
& $\mathrm{N}$ & &
\end{tabular}

Since the two variables had no major link, it means that there was no effect in students' reading achievement. As $\mathrm{H}_{1}$ was rejected, it was not necessary to do regression analysis. As a result, to reinforce the value of this study, the interpretation was made based on the result of data analysis. Based on the findings, there was no link between classroom climate and reading achievement of students at one state junior high school in Palembang, South Sumatera, Indonesia. It occured because classroom climate was not the only thing that affects reading achievement. I thought that 
there were some elements affecting students' reading achievement. Geske and Ozola (2008) state there are some elements that persuade learners' reading achievement; such as: social-economic factors of student's family, collaboration of a student and his/her family, student's reading out of school and student's reading at school. The main factor found in this research was learner's reading out of school, so, in this research, the classroom climate was not the main factor. It was also supported by the interview I hold to students. I found most of the students did not like reading out of school. Some of them even said that they did not ever read the book, magazine, newspaper out of the school. In addition, there was no major influence of classroom climate on reading achievement of the students at one state junior high school in Palembang, South Sumatera, Indonesia.

\section{Conclusions}

Based on the findings and interpretations presented above, it can be said that classroom climate and reading achievement had no link. The finding indicated that the null hypothesis (Ho) was fulfilled and the alternative hypothesis (H1) was not accepted. The result also indicated that classroom climate did not help the learners' reading achievement.

\section{References}

Abrar, M., Mukminin, A., Habibi, A., Asyrafi, F., Makmur, M.,\& Marzulina, L.(2018)."If our English isn't a language, what is it?" Indonesian EFL student teachers' challenges speaking English. The Qualitative Report, 23(1), 129-145. Retrieved from http:/ / nsuworks.nova.edu/tqr/vol23/iss1/9

Ariesca, A., \& Marzulina, L. (2016).Teaching Reading Narrative Text by Using Window Notes Strategy to the Eighth Grade Students of SMP Muhammadiyah 4 Palembang. Edukasi: Jurnal Pendidikan Dan Pengajaran, 3(1), 23-32.

Cline, F., Johnson, C., \& King, T. (2006). Focus group reactions to three definitions of reading (as originally developed in support of NARAP goal. Minneapolis, MN: National Accessible Reading Assessment Projects.

Creswell, J. W. (2012). Educational research: planning, conducting, and evaluating quantitative and qualitative research (4th Ed.). Upper Saddle River, NJ: Pearson Education, Inc.

Cropley, A. J. (1992). More ways than one: fostering creativity. New York, NY: Ablex Publishing Corporation.

Debat, E. F. (2006). Applying current approaches to the teaching of reading. English Teaching Forum, 44(1), 8-15.

Doyle, W. (1980).Classroom management, West Lafayette: Kappa Delta Pi.

Ehrenberg, R. G., Brewer, D. J., Gamoran, A., \& Williams, J. D. (2001).Class size and student achievement. Psychological Science in the public interest, 2(1), 1-30.

Fisher, D. L., \& Fraser, B. J. (1981). Validity and use my class inventory (MCI). Science Education, 65, 14-156.

Fleenor, L. (2015). The relationship between student perception of classroom climate and TVAAS students achievement. (Dissertation). East Tennessee State University, United States.

Frank, E., \& Rosen, M. (2010).On the importance of a school and classroom climate for student achievement in reading literacy. Journal Sweden.

Fraser, B. J. (1994). Research on classroom and school climate: Handbook of research on science teaching and learning. New York, NY: Macmillan.

Fraser, B. J. (1998). Classroom environment instruments: Development, validity, and applications. Learning Environment Research, 1(1), 7-34. Fraser, B. J., \& Pickett, L. (2010). Creating and assessing positive classroom learning environments. Childhood Education, Retrieved from http://www.highbeam.com 
Freeman, D. L., \& Long, M. H. (1991). An introduction to second language acquisition research. London, UK: Longman.

Garnet, S. (2005). Using brain power in the classroom: five steps to accelerate learning. New York, NY: Rutledge.

Gedamu, A. D \& Siyawik, Y. A. (2014). Relationship between students' perceived EFL classroom climate and their achievement in English language. Science, Technology and Arts Research Journal, 3(4).187-192.

Grabe, W., \&Stoller, F. L. (2001). Reading for academic purpose: Guidelines for ESL/EFL teachers. In: M celce-Murcia (Ed.), Teaching English as a second or foreign language. Boston, MA: Heinle and Heinle.

Hamra, A., \&Syatriana, E. (2010).Pengembangan model pembelajaran membaca pemahaman sekolah menengah lanjutan( A model of teaching reading comprehension for junior and senior high school). Makassar, Indonesia: Makassar State University Press.

Koth, C. W., Bradshaw, C. P., \& Leaf, P. J. (2008). A multilevel study of predictors of student perceptions of school climate: the effect of classroom level factors. Journal of Educational Psychology, 5(1), 96.

Latha, R. H. (2005). A reading elementary school. English Teaching Forum, 43(1),18-23.

Leone, S. (2009). The relationship between classroom climate variables and students achievement. Ohio, USA: Bowling Green State University.

Martin, N. \& Baldwin, B. (1993a). An examination of construct validity of the inventory of classroom management style. New Orleans, LA: Educational Research.

Marzulina, L. (2018). Learning strategy towards students' descriptive writing achievement taught by using Pick-List-Evaluate-Active -Supply-End Strategy. Edukasi: Jurnal Pendidikan Dan Pengajaran.5(1),63-75.

Marzulina, L., \& Rumainah.(2018). Undergraduate students' reading interest and reading comprehension achievement in a state islamic University. Ta'dib.journal of Islamic education.23(1).54-64.

Mucherarh, W., Finch, H., \& Smith, V. (2014).Exploring the relationship between classroom climate, reading motivation, and achievement: a look into 7 grade classrooms. International Journal of Learning, Teaching, and Educational Research, 8(1), 93-110.

Munaf, Y. (2002). Upaya meningkatkan minat baca siswa.Jurnal Pendidikan Bahasa Sastra Dan Seni, $3(2), 241-250$.

Murray, H. A. (1938). Language teaching methodology. London, UK: Prentice Hall International.

Nix, K. R., Fraser, B. J., \& Ledbetter, E. C. (2003).Evaluating an Integrated Science Learning Environment (ISLE) using a new form of the Constructivist Learning Environment Survey (CLES). Chicago, LA: American Educational Research Association.

Nunan, D. (1991). Language teaching methodology. London, UK: Prentice Hall International.

Palani. (2012). Promoting reading habits and creating literate society. International Referred Research Journal, 3(2), 90-94.

Putra, H., \& Marzulina, L. (2015).Teaching reading comprehension by using Content-based instruction(CBI)method to the second year learners at MTSAl-furqon Prabumulih. Edukasi: Jurnal Pendidikan dan Pengajaran, 2 (1), 1-12.

Surham.(2014). Thecorrelation between classroom climate and students' achievement at MAN 1 Pekanbaru. (UndergraduateThesis).Universitas Islam Negeri Sultan SyarifKasim,Pekanbaru, Riau.

Taylor, P. C.,\& Fraser, B. J. (1991).Development of an instrument for assessing constructivist learning environments. New Orleans, LA: Educational Research Association.

Wasliman, L. (2003). Kualitas Pendidikan sangat memprihatinkan. Retrieved from http://www.Pikiran-Rakyat.com/cetak/0703/11/04xl.htm-17k. 